\title{
Verbal Tradition as a Cultural Power in Building Civilization
}

\author{
Nur Hadi \\ Sociology Department, Social Faculty \\ Universitas Negeri Malang \\ Malang, Indonesia \\ nur.hadi.fis@um.ac.id
}

\begin{abstract}
Tengger community shows a social phenomenon that is strongly influenced by verbal tradition. Their condition, which is in an intersection, between the desire to preserve tradition and change direction into modernization, needs to get a deep and critical appreciation. This research was conducted by using Spradley model in qualitative ethnographic approach with a progressive developing plot. The research was located in Ngadisari, Wonokitri, and Ranupani Village. The researcher also did a cross-analysis approach with a synchronous comparative model to the same symptoms of the Tengger community in Ngadas Village, Malang. The result showed that, first, the main source of Tengger community strap is the existence of verbal tradition. Second, the name of Tengger in mythology is associated with Kasada rites and life of a married couple name "Roro AnTENG and Joko SeGER. Third, verbal tradition has a direct relationship with the social life of Tengger community, and provides an existing foundation for the society to enter the modern life.
\end{abstract}

Keywords-Verbal tradition, Tengger community, Cultural power, Civilization

\section{INTRODUCTION}

Tengger community already has their own religious belief system that contains various elements, i.e. conceptions of supernatural creatures, both good and evil, ancestral spirits, and the supreme God and universe creator (cosmogony), also problem of the shape and character of the world and nature (cosmology), and conceptions of life and death, specifically about world and hereafter. In addition, they have belief system and ideas, learning manners, religion rules, and sacred fairy tales about their Gods history.

Legend is a narrative folk tale which is perceived by the involved community as an event that truly ever happened. Legend has a secular nature that happened in the past. Legend is often seen as a folk history, although that "history" has been distorted because it was unwritten [1]. In Tengger mythology, there is a legend or fairy tale of "Roro AnTeng and Joko SeGER" delivered verbally for generations. It describes Tengger community ancestors which came from the Majapahit Kingdom. This sacred mythology became the background of Kasada ceremony birth and has been believed by the whole Tengger community. They always preserve the customs which are inherited from their ancestors, and always bound in a sense of togetherness. Until now, they still hold the traditions and sublime essential values [2].

Besides the mythology of "Roro AnTeng and Joko SeGER", there is also another mythology that physically became a cultural background of three sacred landscapes: Mount Bromo crater - Mount Batok - sand sea. Sacred story of Tengger community pioneers and establishment of several sacred sites around Mount Bromo become a collective memory of all Tengger communities until now. They also apply the other cultural traits that is called Ma-Lima. It is an ethic or etiquette which orders a man not doing a bad deed, i.e. Maling (stealing), Main (promiscuity), Madat, Minum (quaffing alcohol), and Madon . This theory is commonly applied by various communities in Indonesia, but for Tengger community there are five additional values which must be precisely applied (Wa-Lima) and embodied in life, i.e.: (1) Waras, meaning physical and spiritual health, (2) Wareg, meaning well-fed, (3) Wastra, meaning decent clothing, (4) Wasis, meaning proficient or clever, and (5) Wismo, meaning residential homes [3].

Socio-cultural relations in Tengger community always seem friendly, peace and harmony. It can be seen from the relationship between the community members across ages, genders and religions. This relationship occurs to the whole Tengger communities, even in different groups (interests, political aspirations, and religions), and also in a family whose members have different religious beliefs [4]. This phenomenon occurs due to the socialization successfully done by the older ones to the younger generations. Verbal traditions become an important tool in that socialization process. Berger and Luckmann argued socialization from a sociology aspect; the process of tradition values learning among the society follows such patterns as: objectification, internalization, and subjectification [5].

Such socialization process will shape the child's personality in Tengger community. According to Kardiner et al, basic personality structure is the essence of personality of most society members, as a result of their experience in the same childhood [6]. This basic personality structure is actually to adjust the individual's personality and it is common to all individuals in the society. In forming the 
basic personality structure, there are two elements that have a great influence namely kinship organization (family organization) and community cultural system. The first element concerns with an exclusive feeling forming system, fundamental rules system, how to feed and wean the infants, children's care of painstaking or neglecting, bowel training, ban on sexual liaison, and how to fulfil the primary needs. The second element is related to the prohibition (taboo system), beliefs, ceremonies, folklore, and the way to deal with them [7]. The other matters associated with the process of value inheritance are the social status of public figures and elder people in Tengger community. The status or social standing is a person's place or position in the social group [8].

Tengger community performs rituals under big trees and considers those trees as a sacred place for Danyang. This condition will safeguard the natural environment of Tengger that desperately needs a permanent life spring. The large trees can become a catalyst for spring's availability. In modernization era of science and technology progression that goes into Tengger today, Tengger community must be protected from the possibility of the interest of the outsiders that do not understand their local wisdom in imposition to change the tradition. As an open society, Tengger community has a right to access information, including the absorbed culture and religion from the outside that should be supported. However, their desire to maintain the traditions that bring benefit for life in a unique space should be protected.

After G.30.S/PKI event, many people of Tengger community were arrested because they did not have any religion and "just" wing beliefs. The horror happened when Tengger community leaders were forced to have religion recognized as the State religions, i.e. Buddhism, Hinduism, Islam, and Christian. Kasada ceremony is social bonding for Tengger community that already embraced those State religions. The purposes of this study namely (1) describing the verbal tradition of "Roro AnTeng and Joko SeGER" as a sacred story that unites Tengger community, and affects all activities through various periodic rituals; (2) describing the name of Tengger related to Kasada ceremony and their local knowledge dealing with the limited natural environment; and (3) describing and analyzing the relationship between the verbal tradition and the social life of Tengger community in modern era.

\section{METHOD}

This study used a qualitative approach with ethnographic technique because this research is related to tribal society pristine and closely tied to traditions [9]. The data were analyzed by using Spradley model (progressive developing plot) and interactive analysis developed by Miles and Huberman, including: data reduction, data presentation, and conclusion withdrawal [10]. Several criteria were used to ensure the data validity collected during the research, such as the degree of confidence, distraction, dependence, and certainty [11].The research was conducted in Ngadisari Village, Probolinggo. The researcher also did cross-analysis approach with a synchronous comparative model to the same symptoms of Tengger community in Ngadas Village, Malang. Both communities were selected because each of them follows the different religious orientation (Hindu and Buddhist), assumed can give effect to the traditional ritual changing that framed by verbal tradition.

The primary data sources for this study consisted of Tengger Sharman Head, Sharman Assistant (Wong Sepuh and Pak Legen), formal and informal leaders, and some residents concerned. They were selected based on the purposive sampling in to obtain the complete data, according to the research objectives [12]. The data were collected using several techniques, i.e. (1) observation, to find out Kasada ceremony process and education value inheritance to young generation that occurs with all its social implications, involving various social groups and community leaders; (2) in-depth interviews in participatory manner up to saturated point, to get the description of "Roro AnTeng and Joko SeGER" mythology, their perception, its relation with the modernization nowadays and its effects on their various social life aspects; and (3) documentation study to gather the important information related to the subject and object research which located in the relevant instance and analyze it.

\section{FINDINGS AND DISCUSSION}

\section{A. Verbal Tradition of "Roro AnTeng and Joko SeGER" As A Sacred Story that Unites Tengger Community and Affecst All Their Lives Activities through Various Periodic Rituals}

Based on verbal tradition, it was told that when Majapahit Kingdom collapsed around 14th century, its two officers namely Ki Tumenggung Tunggul Puyung and Ki Ageng Ngawi were accompanied by his son namely Joko SeGer to leave Majapahit Kingdom centre and look for the new areas for their futurelife. Finally, Grinting forest was selected for the new settlement, and then this area developed rapidly. This area was then attended by a princess (Roro) known as "Roro AnTeng", with her family. Roro AnTeng and Joko SeGER had a love relationship and they got married. The merger of their behalf fragment name became a community flagging: TengGer. Because they did not have any children for a long time, the couple decided to be imprisoned at Mount Bromo, until they were granted some children with one requirement that was one of their children had to be sacrificed to the Mount Bromo crater. Until having 25 children, they "forgot" the requirement from Bromopromise God. Mount Bromo then erupted as a sign that the Gods reminded their promise. The fire from Mount Bromo eruption shot out up to Pananjakan and dragged their youngest son, Raden Kusuma, to get into the Mount Bromo crater.

Raden Kusuma was considered to be taken by Bromo God. Therefore, since that time the entire Roro AnTeng and Joko SeGER descendants lose Raden Kusuma, which was on 15th of Full Moon, they had to sacrifice some crops for the whole community Tengger welfare. That annual ceremony is then commonly known as Kasada ceremony, which has strengthened Tengger community solidarity bonds as a unity, 
and become their bonding emotions with the natural environment of the mountains that has given them the economic livelihood.

Verbal tradition, because it is unwritten, could be distorted [1]. However, verbal "history" delivered periodically and continuously to a community, accompanied by the traditional ceremony, can be strengthened. This happened in case of Tengger. Until now, they still hold the sublime tradition and essential values [2]. They also still run Wa-Lima values [3]. Similarly, Tengger community sociocultural relation is always friendly, peace, and harmony. It can be seen on the relationship between the community members across ages, genders, and religions [4].

\section{B. The Connection of Tengger Name, Kasada Rite and Local Knowledge Dealing with Limited Natural Environment}

The name of Tengger has been known since Majapahit Kingdom, based on Tengger inscription findings of 851 Saka year (929 AD) that mentions the name of a village called Walandit, which is a holy place because it is inhabited by Hulun or servant of Hindu Gods in Tengger mountain. Thus, the selection of this location, as a place of refuge during Majapahit Kingdom was attacked by Demak Kingdom and some Islam north coast areas of Java, has been considered carefully by Hindu Majapahit followers. Since then, the cultural and geographical isolation that occurred in several centuries during the general development traditions of Hindu had led Tengger community to develop its own cultural traditions, including the unique religion, which seems as animism, according to the natural condition of the mountains and society development.

Unlike wetlands farming community (paddy field) which holds many ceremonies since seed selection process, planting, until harvesting that spends high cost, Tengger community holds agricultural ceremony only once a year at Kasada ceremony, involving all societies. Kasada ritual seems a unique social dynamics of Tengger community. On one side, it takes place an individualized agricultural land process and requires persistence and self-filled ability which produces the optimal amount of materials. On another side, the rituals that run together in a year ask for the solidarity and high cooperative spirit. The configuration of selfish individualism spirit, that emphasizes on the achievement and communalism that underlies living together, has become an important part of their lives in conducting a harmony life. It also describes the success of socialization process that they keep to the younger generation. Hence, the tradition continuity is maintained. Verbal tradition becomes an important tool in that socialization process [5]. In addition, it has been the basic personality of this community owned by most of the society members, as a result of their experiences at the same childhood [6].

\section{Relation of Verbal Tradition and Social Life of Tengger Community in Modern Era}

After G.30.S/PKI event, many people in Tengger were arrested because they were considered to have no religion and "just" wing beliefs. The horror happened when Tengger community leaders were forced to have religion recognized as the State religions, i.e. Buddhism, Hinduism, Islam, and Christian.In this period, several worship places of each follower adorned Tengger region with all its consequences. Beside the religious plot, Tengger region has been divided into four districts in East Java. From the map of thosefour districts, it seems that Tengger is the tail of each district ofPasuruan, Probolinggo, Malang and Lumajang. The division of Tengger region into four districts done with Tengger community discussion is uncertain, but these divisions cause the colour of their life as a mountain community with a unique socio-cultural and ethnic in its development becomes fade. Each Tengger village has been oriented toward each district.

As the same mountain community with the similar historical background, Tengger villages have small opportunity to integrally make choices and develop themselves. Marginality that has been occurred does not benefit them in uniting themselves as a compacted ethnic. Fragmentation of each Tengger village population causes inequality between the villages in different districts. The existence of natural and cultural tourism assets becomes can be exploited by each district government and outside institutions of Tengger. Likewise, inequality steps of Tengger community in facing the external challenges makes people are no longer one. The district arrogances in claiming the area then appear that they are the native Tengger community and the outsiders have changed. It is not beneficial in their socio-cultural development facing with science and technology evolution for the future life.

\section{CONCLUSION}

From the research conducted, it can be concluded that: (1) The main source of Tengger community bonding is verbal tradition, which is regarded as a sacred story and affects all people's life activities through the various periodic rituals; (2) The name of Tengger in mythology is associated with Kasada rites and life of a married couple namely "Roro AnTENG and Joko SeGER". It is the myth of sacrifice of their youngest child (Raden Kusuma) and the phenomenon of pulling over the variety of crops in Kasada rite routinely which form the local wisdom of Tengger community dealing with the limited natural environment; and (3) verbal tradition has a direct relationship with the social life of Tengger community, and provides a foundation for the community to enter the modern life. The suggestions that can be submitted that as an open society, Tengger community has rights to access the information, including absorbing the culture and religion from the outside that should be supported, but their desire to maintain the traditions that bring benefit for life in a unique space should be protected.

\section{REFERENCES}

[1] J. Danandjaja, Folklor Indonesia, Ilmu Gosip, Dongeng, dan lainlain. Jakarta: Pustaka Utama Grafiti, 1997.

[2] R. W. Hefner, The Political Economy of Mountain Java An Interpretive History. California: University of California Press, 1990. 
[3] K. Ismain and N. Hadi, Sejarah dan Budaya: dari Masa Kuno sampai Kontemporer. Malang: UM Press, 2003.

[4] Sumartini and N. Hadi, Pedoman Model Toleransi Kehidupan Beragama dari Pengalaman Sosial Budaya Komunitas Tengger, Desa Ngadas, Kabupaten Malang. Malang: Cakrawala Indonesia, 2010.

[5] P. L. Berger and T. Luckman, Tafsir Sosial Atas Kenyataan, Risalah Tentang Sosiologi Pengetahuan. Jakarta: LP3ES, 2000.

[6] A. Kardiner, R. Linton, and C. Du Bois, Psychological Frontiers of Society. New York: Columbia University Press, 1999.

[7] J. Danandjaja, Antropologi Psikologi: Teori, Metode dan Sejarah Perkembangannya. Jakarta: Rajawali Press, 1998.
[8] S. Soekanto, Sosiologi: suatu pengantar. Jakarta: Rajawali Pers, 2000 .

[9] J. P. Spradley, Metode Etnografi. Yogyakarta: Tiara Wacana, 2010.

[10] M. B. Miles and A. M. Huberman, Analisis Data Kualitatif. Jakarta: UI Press, 2002.

[11] L. J. Moleong, Metode Penelitian Kualitatif. Bandung: PT. Remaja Rosdakarya, 2005.

[12] S. Nasution, Metode Penelitian Naturalistik Kualitatif. Bandung Tarsito. 